\title{
Effectiveness of GABA agonist for treatment in mice with complete freud's adjuvants induced chronic pain: molecular modeling approach
}

\author{
Fifteen Aprila Fajrin \\ Laboratory of Clinical Pharmacy, Faculty of Pharmacy, University of Jember, East Java, Indonesia
}

\begin{abstract}
The present study was designed to investigate the effectiveness of gaba agonist in behavioral changes of inflammatory mice with molecular docking approach. Forty mice were divided into 8 groups i.e. sham, gabapentin (10, 30 and 100 nmol), baclofen $(1,10$ and $30 \mathrm{nmol})$ and negative control. Chronic pain was induced by inflammatory agent such as Complete Freud's Adjuvant (CFA). On day 8 after intraplantar injection of CFA, mice were treated by intrathecal with normal saline (sham and negative control groups), gabapentin and baclofen with three different doses, once a day for seven consecutive days. Latency time toward thermal stimulus was measured on days 1,2,8,9,11 and 15 after induction. The molecular docking was examined by Mollegro virtual docker program. The result showed that intrathecal injection of gabapentin and baclofen increased time latency toward thermal stimulus compared to negative control. There were differences between gabapentin and baclofen doses for chronic pain treatment. Molecular docking showed that the differences of effective dose were related to type of amino acid binding between gabapentin and baclofen.
\end{abstract}

Key Words: Gabapentin, baclofen, dorsal horn, CFA, molecular docking.

\section{INTRODUCTION}

Generally, many diseases are represented with pain. Although pain is a simple condition, but without an appropriate therapy will lead to chronic pain condition. Chronic pain incidence impacts to many several problems in patient life such as economic, social and psychology (Breivik, 2005; Mallen, et al., 2005). International Association for the study of Pain (IASP) define that pain is an unpleasant sensory and emotional experience, usually associated with actual and potential tissue damage (IASP, 2011). Chronic pain incidence is the most symptom that was happened in 1 of 6 people on the population (Xie, 2011). The prevalence of chronic pain in Europe was estimated to 55.2\% (Picavet and Schouten, 2003; Harstall and Ospina, 2003). There were no clearly estimation in Indonesia, but Kartini (2007) showed that $25-50 \%$ of geriatry patient have pain. Until now, chronic pain treatment is still a challenge because of its complex mechanism. Morphine as the first

\footnotetext{
*Corresponding Author:

Fifteen Aprila Fajrin, Lecturer and Researcher

Laboratory of Clinical Pharmacy, Faculty of Pharmacy

Jl. Kalimantan 1 No. 2 Kampus Tegal Boto Jember, 68121

University of Jember, East Java, Indonesia

E-mail: fiezz_15@yahoo.co.id

Contact No.: +62-8563175010
}

treatment have a lot of weakness and the effectiveness of this drug for chronic pain treatment is still debated (Baron et al., 2010; Hahm et al., 2011). So, we need an alternative new strategy, one of them is GABAergik agonist drugs such as gabapentin and baclofen (Wang et al., 2007).

\section{MATERIALS AND METHODS}

\section{Chemicals and Drugs}

Gabapentin, Baclofen, Complete Freud's Adjuvant (CFA) and Neutral Buffer Formalin (NBF) 10\% were pharmaceutical analysis and purchased from Sigma. Aether for anaesthetic was pharmaceutical analysis and purchased from E-Merck.

\section{Experimental Animals}

Forty 8-week-old mice (males) were used for the experiment. They were purchased and kept in the Animal House, College of Pharmacy, University of Airlangga, Surabaya, East Java, Indonesia. The temperature of the room was maintained at $26-28^{\circ} \mathrm{C}$ with a 12-hour light/12-hour dark cycle. Forty mice were divided into eight group i.e. sham, negative control, gabapentin treatment $(10,30$ and 100nmol) and baclofen treatment (1, 10 and 30nmol). All 
Table 1: Time Latency toward thermal stimulus between sham group and inflammatory (CFA) group on day 1, 2 and 8.

\begin{tabular}{lccc}
\hline \multirow{2}{*}{ Groups } & \multicolumn{2}{c}{$\begin{array}{c}\text { Average of time latency toward thermal } \\
\text { stimulus on day - (second } \pm \text { SEM) }\end{array}$} \\
\cline { 2 - 4 } & $\mathbf{1}$ & $\mathbf{2}$ & $\mathbf{8}$ \\
\hline $\begin{array}{c}\text { Sham }(\mathrm{n}=5) \\
\text { Inflammation/CFA } \\
(\mathrm{n}=35)\end{array}$ & $9.8 \pm 0.4$ & $8.7 \pm 0.3^{*}$ & $10.0 \pm 0.6^{*}$ \\
& $9.7 \pm 0.2$ & $6.7 \pm 0.1^{*}$ & $4.4 \pm 0.1^{*}$ \\
*significant difference of average time latency toward thermal stimulus \\
$\begin{array}{l}\text { between Sham and CFA groups on day 2 and 8 ( } p<0.001 ; \text { independent } t \text { test } \\
\text { at 95\%) }\end{array}$
\end{tabular}

treatment in animal have been approved by Animal Care and Use Committee (ACUC) from Faculty of Veterinary Medicine, Airlangga University, Surabaya, East Java, Indonesia.

\section{Molecular Modelling Programs}

Computer programs in this research were ChemBioDraw Ultra ${ }^{\circledR} 11.0$ trial edition (2D structure and determining of physicochemical properties), ChemBio3D Ultra ${ }^{\circledR} 11.0$ trial edition (3D structure) and Mollegro Virtual Docker 5.0 (Docking).

\section{Experimental Protocol}

CFA-induced Chronic Pain Method

Intraplantar injection were performed with a Hamilton syringe coupled to a 26-gauge needle. Fourty microliters of CFA (Sigma-Aldrich) was injected by intraplantar into the plantar surface of the hind paw under aether anesthesia for induction of inflammation in inflammatory (CFA) groups. Control mice (sham group) received fourty microliters normal saline as CFA replacement.

Behavioral Testing Method

Animals were placed on a hot plate, which was set to $48 \pm 0.5^{\circ} \mathrm{C}$, and timing was started immediately.
The time until nociceptive behavior (defined as lifting, shaking, or licking the injured paw) occurred was recorded for each animal and the animal immediately removed from the hot plate. Latency time toward thermal stimulus were measured on day $1,2,8,9,11$ and 15 .

\section{Drugs Treatment}

Gabapentin and baclofen were disolved in physiological saline for intrathecal injection. Intrathecal injections were given in a volume of $5 \mu \mathrm{l}$. In control mice (sham group) and negative control were given by physiological saline at the same volume. Gabapentin and baclofen were administrated in three different doses, once a day for seven consecutive days, started from day 8 after CFA induction. Gabapentin were given on doses 10,30 and 100 nmol. Baclofen were given on doses 1,10 and $30 \mathrm{nmol}$.

\section{Statistics Analysis}

Data were presented as mean \pm SEM. The time latency toward thermal stimulus between inflammatory (CFA) and sham group were analyzed by independent $\mathrm{t}$-test. The time latency toward thermal stimulus between each treatment were analyzed with two-way ANOVA. Differences were considered statistically significant at the $p<0.05$ confidence interval.

\section{Molecular docking Analysis}

The structures of the compounds under study have been drawn in $2 \mathrm{D}$ ChemDraw ${ }^{\circledR}$ and then converted into 3D modules using the default conversion procedure implemented in the CS Chem 3D Ultra ${ }^{\circledR}$. The generated 3D-structures of the compounds were subsequently subjected to energy minimi-

Table 2: Time latency toward thermal stimulus after gabapentin and baclofen treatment on mice with inflammatory pain on day 9,11 and 15 .

\begin{tabular}{|c|c|c|c|c|}
\hline \multirow{2}{*}{ Groups } & \multirow{2}{*}{ Treatment } & \multicolumn{3}{|c|}{ Average time toward thermal stimulus on Day- (second \pm SEM) } \\
\hline & & 9 & 11 & 15 \\
\hline \multirow[t]{4}{*}{ Sham } & Normal saline & $10.3 \pm 0.5$ & $10.1 \pm 0.6$ & $10.2 \pm 0.8^{\mathrm{a})}$ \\
\hline & Normal saline & $4.5 \pm 0.5$ & $4.1 \pm 0.4$ & $3.7 \pm 0.6^{\mathrm{b})}$ \\
\hline & Gabapentin $10 \mathrm{nmol}$ & $6.2 \pm 0.4$ & $8.0 \pm 0.2$ & $9.1 \pm 0.5^{\mathrm{c})}$ \\
\hline & Gabapentin $30 \mathrm{nmol}$ & $7.6 \pm 0.7$ & $8.3 \pm 0.6$ & $10.5 \pm 0.7 \mathrm{ac})$ \\
\hline \multirow[t]{4}{*}{ CFA } & Gabapentin $100 \mathrm{nmol}$ & $9.2 \pm 0.6$ & $11.0 \pm 0.9$ & $12.9 \pm 0.4^{\mathrm{d})}$ \\
\hline & Baclofen $1 \mathrm{nmol}$ & $6.5 \pm 0.4$ & $7.6 \pm 0.5$ & $9.9 \pm 0.6^{c)}$ \\
\hline & Baclofen $10 \mathrm{nmol}$ & $7.0 \pm 0.4$ & $8.0 \pm 0.6$ & $10.4 \pm 0.3^{\mathrm{a})}$ \\
\hline & Baclofen $30 \mathrm{nmol}$ & $8.0 \pm 0.5$ & $9.2 \pm 0.3$ & $11.5 \pm 0.6^{\mathrm{ad})}$ \\
\hline
\end{tabular}




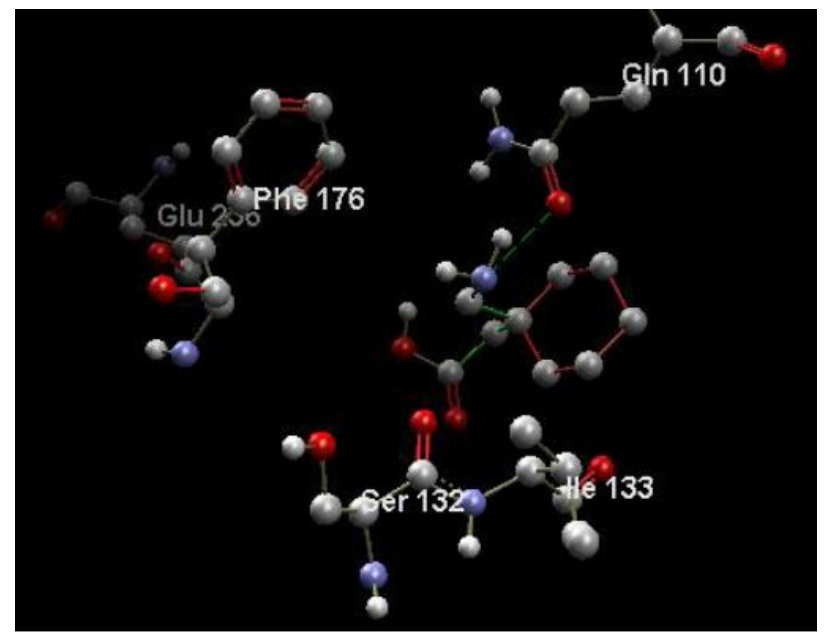

Figure 1: Hydrogen Bond Interaction Between Gabapentin and NR2B Subunit of NMDA Receptor.

zation and all these energy minimized structures were saved in SYBIL form and exported to Mollegro Virtual Docker (MVD) 5.0 (www.mollegro.com) software for the computation. For our study, we used biological database like PDB (protein data bank). The PDB (Protein Data Bank) is the single worldwide archive of Structural data of Biological macromolecules, established in Brookhaven National Laboratories (BNL) in 1971 (The Protein Data Bank, 2000). It contains Structural information of the macromolecules determined by X-ray crystallographic, NMR methods etc. In this study we used NMDA receptor NR2B subunit (3QEM) with ifenprodil as native ligand (www.pdb.org). the results were shown as Moldock score, rerank score, RMSD and Hbond.

\section{RESULTS AND DISCUSSION}

Inflammation induction by intraplantar injection of CFA caused lowering of latency time toward thermal stimulus than before (baseline). The results were showed at Table 1. After intrathecal injection of gabapentin and baclofen, latency toward thermal stimulus increased to normal (closed to sham group). This results showed that effectiveness gabapentin to increased time latency toward thermal stimulus was reached on dose $30 \mathrm{nmol}$. In baclofen treatment, $10 \mathrm{nmol}$ doses was given latency toward thermal stimulus as same as sham group. Latency time toward thermal stimulus were significantly different between day 9, 10 and 15. It means that the longer of day treatment, the longer latency

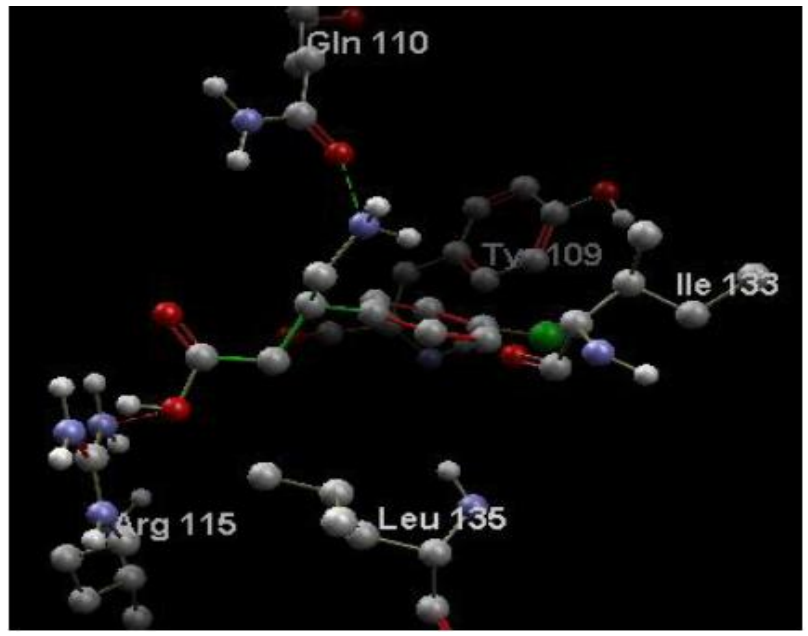

Figure 2: Hydrogen Bond Interaction Between Baclofen and NR2B Subunit of NMDA Receptor.

time toward thermal stimulus. The results were showed at Table 2.

There is a relationship between chronic pain and GABA. Pathophysiology of chronic pain showed that chronic pain is caused by imbalance between GABA (as inhibitory neurotransmitter) and Glutamat, especially NMDA subunit NR2B (as excitatory neurotransmitter). GABA agonist administration cause increasing activity of GABA receptor and lead inhibition of NMDA subunit NR2B release. So, it were relevance when gabapentin and baclofen caused increasing of time latency toward thermal stimulus, because both of them worked to stimulate GABA receptor with two different ways. Gabapentin binds to $\alpha_{2} \delta_{1}$ subunit in $\mathrm{Ca}^{2+}$ canal and inhibits glutamate release (Bee and Dickenson, 2007). The other side, baclofen is an GABAB agonist receptor that stimulates hiperpolarization by increases $\mathrm{K}+$ influx and decreases $\mathrm{Ca}^{2+}$ influx and inhibit glutamate release (Bettler, et al., 2004; Benke et al., 2012).

Based on docking results, gabapentin and baclofen interacted on glutamate site of NR2B subunit. Interaction between gabapentin and baclofen with

Table 3: Docking parameter between ligand and drugs treatment (gabapentin and baclofen) on NR2B subunit of NMDA receptor.

\begin{tabular}{ccccc}
\hline Ligand & $\begin{array}{c}\text { MolDock } \\
\text { Score }\end{array}$ & $\begin{array}{c}\text { Rerank } \\
\text { Score }\end{array}$ & RMSD & HBond \\
\hline Ifendrofil & -148.719 & -125.686 & 0.932391 & -5.24993 \\
Gabapentin & -68.5872 & -80.5263 & 8.73497 & -3.8352 \\
Baclofen & -103.48 & -84.9504 & 8.02481 & -4.47179 \\
\hline
\end{tabular}


NR2B subunit happened by hydrogen bond on amino acid Gln110 (Figure 1). Different from gabapentin, baclofen also bind to Arg115 (Figure 2). The binding differences between gabapentin and baclofen, probably have responsibility to different effectiveness between both of them on NR2B subunit. Docking parameter (Table 3) showed that baclofen have rerank score and hydrogen bond value (-84.9504 and -4.47179$)$ smaller than gabapentin (-80.5263 and -3.8352). Smaller value indicated that binding energy between baclofen and NR2B subunit lower and caused receptor binding more stable than gabapentin. This value, maybe can be used to explain the differences of doses that caused an effectiveness on NR2B subunit inhibition. From the result of latency time toward thermal stimulus showed that effective dose for baclofen was lower $(10 \mathrm{nmol})$ than gabapentin $(30 \mathrm{nmol})$ to interact with NR2B subunit of NMDA receptor.

\section{CONCLUSION}

Gabapentin and baclofen were effective for inflammatory-induced chronic pain in mice and showed that both of them caused increasing of latency time toward thermal stimulus. The differences of the effective doses between gabapentin and baclofen were based on differences type of amino acid binding on NR2B subunit.

\section{REFERENCES}

Baron, R., Binder, A., and Wasner, G. (2010). Neuropathic Pain : Diagnosis, Pathophysiological Mechanisms, and Treatment. The Lancet Neurology, 9: 807-819. [DOI]

Bee, L.A., and Dickenson, A.H. (2007). Neuropathic Pain : Multiple Mechanism at Multiple Sites, Future Neurology, 2(6): 661-671. [DOI]

Benke, D., Zemoura, K., and Maier, P.J. (2012). Modulation of cell surface GABAB Receptors by Desensitization, Trafficking and Regulated Degadration, World Journal of Biological Chemistry, 3(4): 61-72.

Bettler, B., Kaupmann, K., Mosbacher, J., and Gassmann, M. (2004). Molecular Structure and Physiological Functions of GABAB Receptors, Physiological Reviews, 84: 835-867. [DOI] PMid:15269338

Breivik, H., Collett, B., Ventafridda, V., Cohen, R., and Gallacher, D. (2006). Survey of Chronic Pain in Europe: Prevalence, Impact on Daily Life, and Treatment, European Journal of Science, 10: 287-333. [DOI]

Hahm, E.T., Kim, Y., Lee, J.J., and Cho, Y.W (2011). GABAergic Synaptic Response and Its Opioidergic Modulation in Periaqueductal Gray Neurons of Rats with Neuropathic Pain, BMC Neuroscience, 12(41): 2-9. [DOI]

Harstall, C., and Ospina, M. (2003). How Prevalent is Chronic Pain?, Clinical Updates (IASP), 11(2): 1-4.

International Association for the Study of Pain (IASP). (2011). IASP Taxonomy, [LINK] [accessed on October 15 ${ }^{\text {th }}$ 2011]

Kartini. (2007). Hubungan Nyeri dengan Gangguan Aktivitas Interpersonal pada Individu Usia 50 Tahun Keatas di Kabupaten Purworejo. Yogyakarta: Universitas Gadjah Mada.

Mallen, C., Peat, G., Thomas, E., and Croft, P. (2005). Severely Disabling Chronic Pain in Young Adults : Prevalence from a Population-based Postal Survey in North Staffordshire, BMC Musculoskeletal Disorders, 42(6): 1-9. [DOI]

Picavet, H.S.J., and Schouten, J.S.A.G. (2003). Musculosketal Pain in the Netherlands ; Prevalences, Consequences and Risk Groups, the DMC3-study, Pain, 102 : 167-178. [DOI]

Wang, X.L., Zhang, H.M., Chen, S.R., and Pan, H.L. (2007). Altered Synaptic Input and GABAB Receptor Function in Spinal Superficial Dorsal Horn Neurons in Rats with Diabetic Neuropathy, Journal of Physiology, 579(3) : 849861. [DOI]

Xie, W. (2011). Assessment of Pain in Animals In Ma, C., and Zhang, J.M. (Eds). Animal Models of Pain, New York : Humana Press, p. 23-76. [DOI] 